\title{
Deoxyribonucleic Acid Reassociation in the Classification of the 'rhodochrous' Complex and Allied Taxa
}

\author{
By M. MORDARSKI AND K. SZYBA \\ Department of Biosynthesis, Institute of Immunology and Experimental Therapy, \\ Wroclaw, Poland \\ AND G. PULVERER \\ Institute of Hygiene, University of Cologne, \\ Federal Republic of Germany \\ AND M. GOODFELLOW \\ Department of Microbiology, The University, \\ Newcastle upon Tyne NEI ${ }_{7} R U$
}

(Received 6 June 1975)

\begin{abstract}
SUMMARY
The degree of binding was determined between DNA preparations from gordonae and rhodochrous strains and uracil-labelled DNA from five reference strains, Nocardia asteroides NK20, N. pellegrino PI I, Gordona bronchialis TI, G. terrae T5 and rhodochrous strain R90. Most of the rhodochrous and pellegrino strains fell into one of two genetically homogeneous taxa. The nucleotide sequence homology data also suggested that $G$. bronchialis, $G$. rubra, and more equivocally $G$. terrae, formed distinct species. However, the values for DNA relatedness between these species, and between them and the rhodochrous homology groups, were comparatively low. Only a small degree of nucleotide sequence homology was found between the $N$. asteroides reference system and the rest of the taxa studied. The nucleotide composition of the DNA preparations from 29 of the 30 test strains fell between 63 and $69 \mathrm{~mol} \%$ guanine plus cytosine.
\end{abstract}

\section{INTRODUCTION}

An increasing volume of taxonomic data supports the view that the 'rhodochrous' complex should be considered as a taxon equivalent in rank to the genera Nocardia and Mycobacterium (Cross \& Goodfellow, 1973). Much of the data comes from numerical phenetic studies (Bradley, 1971; Goodfellow, 1971; Tacquet et al., 1971; Goodfellow, Fleming \& Sackin, 1972; Jones, 1975) although additional evidence is provided by chemical and serological analyses (Ridell \& Norlin, 1973; Alshamaony, Goodfellow \& Minnikin, 1976a). Recently, in an extensive investigation of rhodochrous and related strains, carried out under the auspices of the International Working Group on Mycobacterial Taxonomy, further concordance was found between phenetic, serological and chemical data (Goodfellow et al., 1974). Representative strains of the proposed genus Gordona (Tsukamura, 197I) were not included in any of these studies and the relationship between this taxon and the 'rhodochrous' complex is not settled. However, on the basis of numerical phenetic data, Tsukamura (1973, 1974) classified a number of rhodochrous strains in the genus Gordona.

In all the numerical studies, the rhodochrous strains formed a distinct but heterogeneous 
taxon. In some instances the strains fell into two clusters (Bradley, I971; Tacquet et al., 1971; Jones, 1975) but in others three or more homogeneous phena were recovered (Goodfellow, I971; Goodfellow et al., 1974). Since few of the cultures examined were common to all of the investigations it is difficult to determine whether or not, and to what extent, phena overlap. It is evident, however, that Nocardia rubra (Bradley, 197I) corresponds at least partially with phenon ${ }_{4}$ C (Goodfellow, I97I), Gordona rhodochroa (Tsukamura, 1973) with phenon I $a$ (Goodfellow et al., I974), and Nocardia erythropolis (Bradley, 197I) can be equated with phenon I4D (Goodfellow, I97I) and phenon $F_{3}$ (Jones, 1975). Further evidence of the heterogeneity of the 'rhodochrous' complex can be drawn from genetic recombination (Adams, Adams \& Brownell, 1970), DNA: DNA pairing (Bradley \& Huitron, 1973; Bradley, Brownell \& Clark, 1973), serological (Ridell, I974) and chemical data (Goodfellow et al., 1974; Alshamaony et al., 1976 b).

In view of the uncertain taxonomy of the 'rhodochrous' complex and related taxa, we have undertaken DNA reassociation assays on such nocardioform bacteria. This preliminary report describes the determination of the degree of binding between DNA preparations from rhodochrous and Gordona strains and uracil-labelled DNA from five reference strains.

\section{METHODS}

Test strains and growth conditions. Details of the strains and their sources are given in Table I. All cultures were maintained routinely on yeast extract agar at room temperature.

For DNA extraction, organisms were grown in submerged culture in modified Sauton's medium (Mordarska, Mordarski \& Goodfellow, 1972) or in peptone yeast extract broth (Bradley, 1973) for 30 to $40 \mathrm{~h}$ at $37{ }^{\circ} \mathrm{C}$. Cultures were checked for purity; and then the organisms were harvested by centrifuging, washed in saline ethylenediaminetetraacetate $(0.15 \mathrm{M}-\mathrm{NaCl}, 0 . \mathrm{I} \mathrm{M}-\mathrm{EDTA}, \mathrm{pH} 8.0)$ and stored at $-20^{\circ} \mathrm{C}$.

Extraction of DNA. Harvested organisms (200 $\mathrm{mg}$ wet $\mathrm{wt}$ ) were suspended in $\mathrm{I} \mathrm{ml}$ of buffer A [0.015 $\mathrm{M}$-Tris- $\mathrm{HCl}(\mathrm{pH} \mathrm{8.0),} 0.45 \mathrm{M}$-sucrose and $0.008 \mathrm{M}$-EDTA] containing I mg lysozyme (Sigma or Serva) $/ \mathrm{ml}$ and incubated for $18 \mathrm{~h}$ at $37^{\circ} \mathrm{C}$. The organisms were then separated by centrifuging, and resuspended in $0.5 \mathrm{ml}$ of buffer $\mathrm{B}$ [0. I M-Tris- $\mathrm{HCl}$ ( $\mathrm{pH} 9.0$ ), $0.01 \mathrm{M}-\mathrm{NaCl}$ and I mM-sodium citrate]. Strains not lysed by lysozyme were treated for $90 \mathrm{~s}$ in a Brown disintegrator; if the lysate was considered to be dense, a little more buffer $B$ was added.

After lysis, sodium dodecyl sulphate (SDS, $2 \%$ w/v) was added and the suspension heated for $30 \mathrm{~min}$ at $60^{\circ} \mathrm{C}$, rapidly cooled and an equal volume of freshly-distilled phenol saturated with Tris-SDS buffer (0.0I M-Tris, I \%, w/v, SDS and $0.1 \mathrm{M}-\mathrm{NaCl}, \mathrm{pH} 9 \cdot 0$ ) added (Saito \& Miura, 1963). The resulting mixture was shaken in a cooled gyratory incubator for $20 \mathrm{~min}$ and the emulsion formed was separated in a cooled centrifuge (10 min, $10000 \mathrm{~g}$ ). The aqueous phase was removed and treated twice again with an equal volume of phenol saturated with the Tris-SDS buffer. Nucleic acids were precipitated from the aqueous fraction by the addition of 2 vols of cooled ethanol $\left(-10^{\circ} \mathrm{C}\right)$. The precipitate was spooled on a glass rod, dissolved in $0 . \mathrm{I} \times \mathrm{SSC}$ (SSC:0.15 $\mathrm{M}-\mathrm{NaCl}$, 0.01 $5 \mathrm{M}$-trisodium citrate), and the salt concentration increased to $\mathrm{I} \times \mathrm{SSC}$ by the addition of $\mathrm{I} 0 \times \mathrm{SSC}$. This solution was incubated at $37{ }^{\circ} \mathrm{C}$ for $30 \mathrm{~min}$ with $50 \mu \mathrm{g}$ pancreatic ribonuclease (Sigma)/ml and preincubated at $100{ }^{\circ} \mathrm{C}$ for $10 \mathrm{~min}$, to destroy DNAase.

After digestion, an equal volume of phenol saturated with water was added and the mixture shaken for $10 \mathrm{~min}$ in a refrigerator. The resulting emulsion was centrifuged and the aqueous phase separated. Phenol extraction was repeated several times, usually three, until 
Table I. Designation, source and DNA base composition of test strains

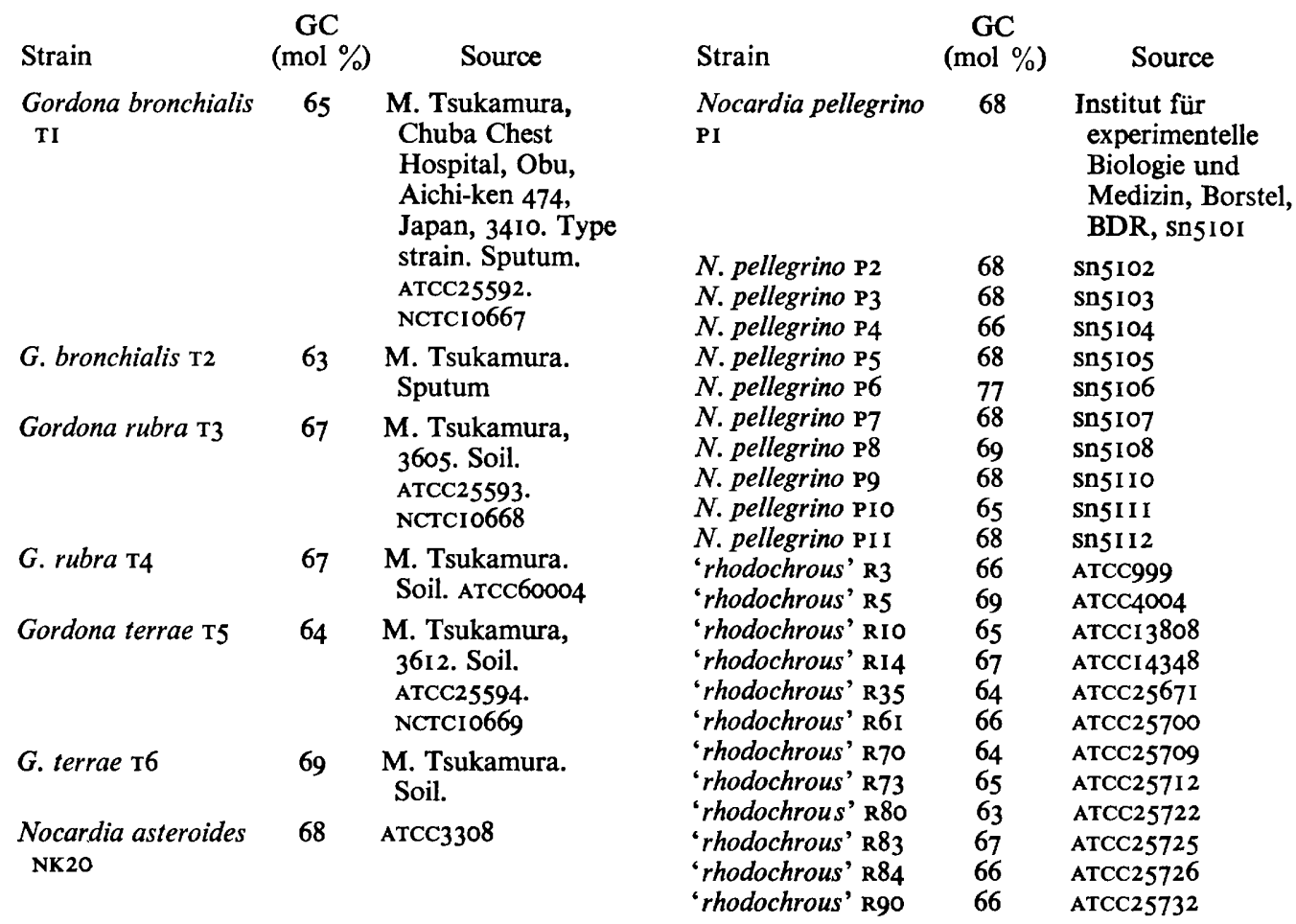

ATCC, American Type Culture Collection, Rockville, Maryland, U.S.A. NCTC, National Collection of Type Cultures, London.

the interphase layer disappeared. The purified DNA was precipitated with cooled ethanol, redissolved in $0 . \mathrm{I} \times \mathrm{SSC}$, and $0 . \mathrm{I}$ vol. of $3.0 \mathrm{M}$-sodium acetate-0.00I M-EDTA solution, $\mathrm{pH} 7 \cdot 0$, was added. The DNA was then precipitated by slowly adding $0.54 \mathrm{Vol}$. of isopropanol, wound on a glass rod, and washed in ethanol solutions of increasing concentration $(70,80$ and $90 \%$ ). After drying, the DNA was redissolved in $0.1 \times \mathrm{SSC}$ and the treatment with isopropanol repeated until a preparation having $E_{260} / E_{280}$ of $\mathbf{I} \cdot 9$ to $2 \cdot 0$ was obtained, and $E_{230} / E_{255}$ was greater than 2. The purified DNA was stored at $5^{\circ} \mathrm{C}$ in $0.1 \times \mathrm{SSC}$ containing a few drops of chloroform.

Preparation of radioactive DNA for homology studies. $\left[2{ }^{14} \mathrm{C}\right]$ Uracil (Nuclear Research Institute, Swierk, Poland), specific activity 9.6 to $12.3 \mathrm{mCi} / \mathrm{mmol}$, was added to inoculated media to give a final concentration of I $\mu \mathrm{Ci} / \mathrm{ml}$. Labelled organisms were centrifuged and the DNA extracted and purified as described. Sheared labelled DNA was prepared by sonication in an ice bath at a frequency of $24 \mathrm{kHz}$ (six periods of $15 \mathrm{~s}$ with $30 \mathrm{~s}$ intervals).

Labelled reference DNA was prepared from five strains: Gordona bronchialis TI (ATCC 25592), G. terrae T5 (ATCC25594), Nocardia asteroides NK20 (ATCC3308), N. pellegrino PI I and the rhodochrous strain R90 (ATCC25732). The specific activities of the reference DNA preparations are shown in Table 2.

Analysis of base compositions. The mol \% guanine plus cytosine was determined by the method of Huang \& Rosenberg (1966).

Fixation of denatured, high molecular weight DNA on membrane filters. The relationships 
between the test strains were established by determining the extent to which single-stranded DNA, immobilized on nitrocellulose membrane filters, bound labelled reference DNA which was in solution. The membrane filter technique of Legault-Demare et al. (1967), as modified by De Ley \& Tijtgat (1970), was used. The ratio of labelled to unlabelled DNA was I: I5.

High molecular weight DNA in $0.1 \times$ SSC $(150 \mu \mathrm{g} / \mathrm{ml})$ was denatured by boiling for Io min at $100^{\circ} \mathrm{C}$, cooled rapidly in an ice bath, and the salt concentration adjusted to $6 \times$ SSC. Immobilized DNA (I $50 \mathrm{mg}$ ) was prepared by allowing the heat denatured DNA

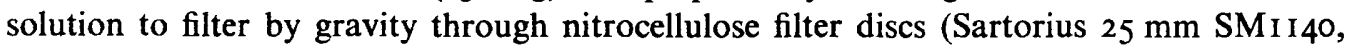
pore size $0.45 \mu \mathrm{m}$ ). The filters were then washed with $50 \mathrm{ml}$ of $6 \times \mathrm{SSC}$, dried at room temperature for $24 \mathrm{~h}$, and placed in a vacuum oven at $80^{\circ} \mathrm{C}$ for $2 \mathrm{~h}$.

$D N A$ : DNA pairing. Filters containing the denatured, unlabelled test DNA were placed in small bottles containing $10 \mu \mathrm{g}$ sheared, denatured labelled reference DNA in $2 \mathrm{ml}$ of $2 \times \mathrm{SSC}$ in $30 \%(\mathrm{v} / \mathrm{v})$ dimethylsulphoxide (DMSO). After incubation for $\mathrm{I} 8 \mathrm{~h}$ at $65{ }^{\circ} \mathrm{C}$ the filters were removed and washed with $50 \mathrm{ml}$ of $2 \times$ SSC-DMSO, then with $50 \mathrm{ml}$ of $2 \times$ SSC. The dried filters were examined for bound radioactivity in a liquid scintillation counter (Nuclear, Chicago) using a scintillation fluid consisting of I 1 toluene, $8 \mathrm{~g} \mathrm{2,5-diphenyl-}$

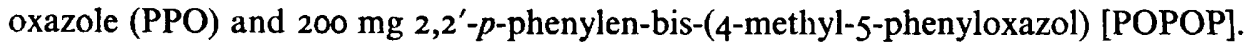

Thermal stability of DNA:DNA duplexes. The thermal stability of duplexes formed between filter-bound DNA and the various reference DNA preparations was determined from the $T_{m(e)}$ values. The midpoint of the thermal elution $\left(T_{m(e)}\right)$ is the temperature at which half of the reassociated reference DNA becomes dissociated and eluted from the test DNA bound to the filter. $\Delta T_{m(e)}$ was found by subtracting $T_{m(e)}$ of hybrids of the heterologous system from $T_{\text {m(e) }}$ of homologous hybrids (Okaniski \& Gregory, 1970).

After pairing, the filters were dried and then eluted with $0 . \mathrm{I} \times \mathrm{SSC}$ solution at temperature increments of $5{ }^{\circ} \mathrm{C}$ over the range 70 to $100{ }^{\circ} \mathrm{C}$. The radioactive samples were assayed in the scintillation fluid of Bray (1960).

\section{RESULTS}

\section{DNA base compositions}

The nucleotide composition of the DNA preparations from 29 of the 30 test strains fell within the range 63 to $69 \mathrm{~mol} \%$ guanine (G) plus cytosine (C). Nocardia pellegrino P6, showed a high GC content of $77 \%$.

\section{$D N A: D N A$ pairing}

The DNA preparations from 9 of the Io strains received as $N$. pellegrino bound significant amounts of reference DNA from $N$. pellegrino PI I but showed little affinity with that from $N$. asteroides NK20, G. bronchialis TI and $G$. terrae T5 (Table 2). The remaining strain, $N$. pellegrino $\mathbf{P 6}$ shared little homology with the $N$. pellegrino reference strain but bound $80 \%$ of the reference DNA from the rhodochrous strain R90. A much smaller degree of nucleotide sequence homology ( 15 to $30 \%$ ) was found between the other $N$. pellegrino strains and the rhodochrous reference strain (Table 2). A typical elution curve of a DNA duplex formed between reference $N$. pellegrino DNA and DNA of a $N$. pellegrino strain is shown in Fig. I.

The DNA preparations of II of the 12 rhodochrous strains bound 60 to $100 \%$ of the reference DNA from the rhodochrous strain R90, but with few exceptions showed a low degree of homology with the other reference systems (Table 3). The remaining rhodochrous culture, R35, showed little nucleotide homology with any of the reference systems. However, very high nucleotide sequence homologies were found between the reference systems and 
Table 2. Reassociation of DNA samples from Nocardia pellegrino strains with the DNA from reference strains N. pellegrino PII, $N$. asteroides NK20, Gordona bronchialis $\mathrm{TI}, G$. terrae $\mathrm{T} 5$ and 'rhodochrous' R90

The extent of binding between DNA from test strains and labelled DNA from reference strains is expressed as a percentage relative to the extent of binding between labelled and unlabelled DNA from the reference strain itself. $\Delta T_{m(e)}$, a measure of the thermal stability of the DNA : DNA duplexes, was obtained by subtracting $T_{m(e)}$, the midpoint of thermal elution, of the molecular hybrids of the heterologous system from the $T_{m(e)}$ of the homologous hybrids. For details of measurement, see Methods.

Labelled DNA source

\begin{tabular}{|c|c|c|c|c|c|c|c|c|c|}
\hline \multirow[b]{2}{*}{ DNA source } & \multicolumn{2}{|c|}{ N. pellegrino PI I } & \multicolumn{2}{|c|}{ N. asteroides NK20 } & \multirow{2}{*}{$\begin{array}{c}\text { G. bronchialis TI } \\
\text { Rel. DNA } \\
\text { bound (\%) }\end{array}$} & \multicolumn{2}{|c|}{ G. terrae T5 } & \multicolumn{2}{|c|}{ 'rhodochrous' R9o } \\
\hline & $\begin{array}{l}\text { Rel. DNA } \\
\text { bound (\%) }\end{array}$ & $\begin{array}{c}\Delta T_{m(e)} \\
\left({ }^{\circ} \mathrm{C}\right)\end{array}$ & $\begin{array}{l}\text { Rel. DNA } \\
\text { bound (\%) }\end{array}$ & $\begin{array}{c}\Delta T_{m(e)} \\
\left({ }^{\circ} \mathrm{C}\right)\end{array}$ & & $\begin{array}{l}\text { Rel. DNA } \\
\text { bound (\%) }\end{array}$ & $\begin{array}{c}\Delta T_{m(e)} \\
\left({ }^{\circ} \mathrm{C}\right)\end{array}$ & $\begin{array}{c}\text { Rel. DNA } \\
\text { bound (\%) }\end{array}$ & $\begin{array}{l}\Delta T_{m(e)} \\
\left({ }^{\circ} \mathrm{C}\right)\end{array}$ \\
\hline N. pellegrino PI I & 100 & 0 & 13 & - & $16 \pm 4$ & $12 \pm 2$ & 3 & $29 \pm 0$ & 3 \\
\hline N. pellegrino PI & $102 \pm 4$ & 0 & 16 & 0 & $16 \pm 2$ & I I \pm I & - & $27 \pm 2$ & 10 \\
\hline N. pellegrino $\mathrm{P2}$ & $82 \pm 2$ & 9 & 12 & 0 & I I \pm I & $11 \pm 2$ & - & $20 \pm I$ & 17 \\
\hline N. pellegrino $\mathbf{P} 3$ & $101 \pm 6$ & 15 & 15 & 0 & $15 \pm 2$ & $12 \pm 0$ & 7 & $26 \pm I$ & - \\
\hline N. pellegrino $\mathrm{P} 4$ & $104 \pm 0$ & 14 & 15 & 9 & $14 \pm I$ & $17 \pm 3$ & - & $30 \pm I$ & 0 \\
\hline N. pellegrino $\mathrm{P} 5$ & $63 \pm I$ & 7 & Io & 0 & $13 \pm I$ & $10 \pm I$ & 14 & $22 \pm I$ & 16 \\
\hline N. pellegrino $\mathrm{P} 6$ & $12 \pm I$ & 3 & 15 & 0 & $16 \pm 2$ & $14 \pm 2$ & I & $8 I \pm 10$ & 10 \\
\hline N. pellegrino $\mathrm{P} 7$ & $89 \pm 2$ & 12 & 15 & 一 & $14 \pm 1$ & $15 \pm 3$ & 10 & $27 \pm 2$ & - \\
\hline N. pellegrino $\mathrm{P} 8$ & $96 \pm 3$ & 10 & I I & - & $2 I \pm 2$ & $10 \pm 0$ & 一 & $22 \pm I$ & - \\
\hline N. pellegrino P9 & $82 \pm 0$ & - & 10 & - & $9 \pm 0$ & $7 \pm 1$ & 9 & $20 \pm 0$ & - \\
\hline$N$. pellegrino $\mathrm{PIO}$ & $104 \pm 4$ & 10 & 17 & - & $17 \pm I$ & $15 \pm 2$ & - & $26 \pm I$ & - \\
\hline N. asteroides $\mathrm{NK} 20$ & 14 & 一 & 100 & - & II \pm 0 & $12 \pm I$ & - & I3 & 一 \\
\hline G. bronchialis TI & $15 \pm I$ & 2 & II & 0 & 100 & $15 \pm 3$ & 一 & $15 \pm I$ & 一 \\
\hline G. terrae т5 & $15 \pm 2$ & 12 & 13 & 4 & $2 \mathrm{I} \pm 4$ & 100 & - & $28 \pm 2$ & - \\
\hline 'rhodochrous' R9O & $3 I \pm 3$ & 14 & 9 & 0 & I3 & II $\pm I$ & - & 100 & 一 \\
\hline
\end{tabular}

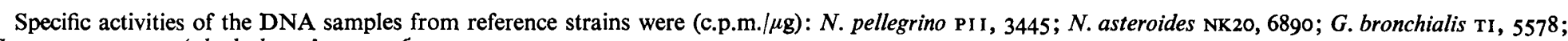
G. terrae T5, 3114; 'rhodochrous' R90, 2764. 
Table 3. Reassociation of DNA samples from rhodochrous strains with DNA from the reference strains 'rhodochrous' R90, Nocardia asteroides $\mathrm{NK} 20, N$. pellegrino $\mathrm{PI} \mathrm{I}$, Gordona bronchialis $\mathrm{T1}$ and G. terrae $\mathrm{T} 5$

\begin{tabular}{|c|c|c|c|c|c|c|c|c|c|}
\hline \multirow[b]{3}{*}{ DNA source } & \multicolumn{9}{|c|}{ Labelled DNA source } \\
\hline & \multicolumn{2}{|c|}{ 'rhodochrous' R90 } & \multicolumn{2}{|c|}{$N$. asteroides NK 20} & \multicolumn{2}{|c|}{ N. pellegrino PII } & \multirow{2}{*}{$\begin{array}{l}\text { G. bronchialis TI } \\
\text { Rel. DNA } \\
\text { bound (\%) }\end{array}$} & \multicolumn{2}{|c|}{ G. terrae T5 } \\
\hline & $\begin{array}{l}\text { Rel. DNA } \\
\text { bound }(\%)\end{array}$ & $\begin{array}{c}\Delta T_{m(e)} \\
\left({ }^{\circ} \mathrm{C}\right)\end{array}$ & $\begin{array}{l}\text { Rel. DNA } \\
\text { bound (\%) }\end{array}$ & $\begin{array}{c}\Delta T_{m(e)} \\
\left({ }^{\circ} \mathrm{C}\right)\end{array}$ & $\begin{array}{l}\text { Rel. DNA } \\
\text { bound ( } \% \text { ) }\end{array}$ & $\begin{array}{c}\Delta T_{m(e)} \\
\left({ }^{\circ} \mathrm{C}\right)\end{array}$ & & $\begin{array}{l}\text { Rel. DNA } \\
\text { bound (\%) }\end{array}$ & $\begin{array}{l}\Delta T_{m(e} \\
\left({ }^{\circ} \mathrm{C}\right)\end{array}$ \\
\hline 'rhodochrous' R3 & $84 \pm 0$ & - & II & 0 & 22 & 7 & I $5 \pm I$ & $15 \pm 3$ & 0 \\
\hline 'rhodochrous' R5 & $>120$ & 17 & 53 & - & $>120$ & - & $>120^{-}$ & $>120$ & $\rightarrow$ \\
\hline 'rhodochrous' R10 & $90 \pm 0$ & II & 8 & 0 & $14 \pm 5$ & 5 & $10 \pm 0$ & $12 \pm I$ & 8 \\
\hline 'rhodochrous' RI4 & $112 \pm 2$ & - & 9 & 4 & $14 \pm 5$ & 8 & $10 \pm 1$ & $15 \pm 3$ & 0 \\
\hline 'rhodochrous' R35 & $8 \pm 3$ & - & 6 & 0 & $16^{-0}$ & - & $14 \pm 1$ & $18 \pm 5$ & 0 \\
\hline 'rhodochrous' R6I & $95 \pm 5$ & 2 & 12 & 0 & $15 \pm 3$ & 0 & $7 \pm 1$ & $15 \pm 0$ & - \\
\hline 'rhodochrous' R70 & $82 \pm 2$ & - & 12 & - & $I I \pm 3$ & - & II \pm 0 & $19 \pm 5$ & 0 \\
\hline 'rhodochrous' R73 & $102 \pm 6$ & - & 12 & 一 & $11 \pm 2$ & 8 & $15 \pm 0$ & $13 \pm 1$ & 12 \\
\hline 'rhodochrous' R80 & $60^{-}$ & 3 & 15 & 4 & 25 & - & II & 15 & 7 \\
\hline 'rhodochrous' R83 & $73 \pm I$ & - & I I & - & $22 \pm 8$ & 14 & $22 \pm 1$ & $28 \pm I$ & - \\
\hline 'rhodochrous' R84 & $85 \pm 3$ & - & 10 & 3 & $27 \pm 2$ & - & $12 \pm 2$ & $22 \pm 0$ & - \\
\hline 'rhodochrous' R9O & 100 & - & 9 & 0 & $3 I \pm 3$ & 14 & $11 \pm 1$ & $13 \pm I$ & 0 \\
\hline$N$. asteroides $\mathrm{NK} 20$ & 13 & 一 & 100 & 0 & 14 & - & $I I \pm I$ & $12 \pm I$ & - \\
\hline N. pellegrino PI I & $29 \pm 0$ & - & 13 & - & 100 & 一 & $12 \pm 2$ & $16 \pm 4$ & 一 \\
\hline G. terrae $\mathrm{T} 5$ & $28 \pm 2$ & 16 & I3 & 0 & $15 \pm 2$ & - & 100 & $21 \pm 4$ & 0 \\
\hline G. terrae $\mathrm{TI}$ & $15 \pm 1$ & - & II & 0 & $15 \pm 1$ & - & I $5 \pm 3$ & $100^{-7}$ & - \\
\hline
\end{tabular}

For definition of $\Delta T_{m(e)}$, and specific activities of DNA from the reference strains, see Table 2. 
Table 4. Reassociation of DNA samples from Gordona strains with DNA from the reference strains G. bronchialis $\mathrm{TI}$, G. terrae T5, Nocardia asteroides NK20, N. pellegrino PI I and 'rhodochrous' $\mathrm{R} 90$

Labelled DNA source

\begin{tabular}{|c|c|c|c|c|c|c|c|c|c|}
\hline \multirow[b]{2}{*}{ DNA source } & \multirow{2}{*}{$\begin{array}{c}\text { G. bronchialis TI } \\
\text { Rel. DNA } \\
\text { bound (\%) }\end{array}$} & \multicolumn{2}{|c|}{ G. terrae $\mathrm{T} 5$} & \multicolumn{2}{|c|}{$N$. asteroides $\mathrm{NK} 20$} & \multicolumn{2}{|c|}{ N. pellegrino PI I } & \multicolumn{2}{|c|}{ 'rhodochrous' R90 } \\
\hline & & $\begin{array}{l}\text { Rel. DNA } \\
\text { bound (\%) }\end{array}$ & $\begin{array}{l}\Delta T_{m(e)} \\
\left({ }^{\circ} \mathrm{C}\right)\end{array}$ & $\begin{array}{l}\text { Rel. DNA } \\
\text { bound (\%) }\end{array}$ & $\begin{array}{l}\Delta T_{m(e)} \\
\left({ }^{\circ} \mathrm{C}\right)\end{array}$ & $\begin{array}{l}\text { Rel. DNA } \\
\text { bound (\%) }\end{array}$ & $\begin{array}{l}\Delta T_{m(e)} \\
\left({ }^{\circ} \mathrm{C}\right)\end{array}$ & $\begin{array}{l}\text { Rel. DNA } \\
\text { bound (\%) }\end{array}$ & $\begin{array}{c}\Delta T_{m(e} \\
\left({ }^{\circ} \mathrm{C}\right)\end{array}$ \\
\hline G. bronchialis TI & 100 & $15 \pm 3$ & 0 & I I & 0 & $15 \pm I$ & 2 & $15 \pm I$ & - \\
\hline G. bronchialis $\mathrm{T} 2$ & 100 & $22 \pm 0$ & 0 & I I & - & $12 \pm 3$ & - & I I \pm 0 & - \\
\hline G. rubra $\mathrm{T} 3$ & 25 & $18 \pm 5$ & 0 & 13 & - & $9 \pm I$ & 一 & $9 \pm 0$ & 一 \\
\hline G. rubra $\mathrm{T} 4$ & $22 \pm I$ & $18 \pm I$ & 0 & 13 & 0 & $15 \pm 2$ & 2 & $14 \pm I$ & 12 \\
\hline G. terrae $\mathrm{T} 5$ & $2 I \pm 4$ & 100 & 0 & 13 & 4 & $15 \pm 2$ & 12 & $28 \pm 2$ & 16 \\
\hline G. terrae $\mathrm{T} 6$ & $16 \pm 3$ & $44 \pm 3$ & 0 & 4 & 0 & $9 \pm 0$ & IO & $8 \pm 0$ & 22 \\
\hline$N$. asteroides $\mathrm{NK} 20$ & II \pm I & $12 \pm I$ & $\ldots$ & 100 & 0 & I4 & 一 & 13 & - \\
\hline N. pellegrino PI I & $12 \pm 2$ & $16 \pm 4$ & 3 & 13 & 一 & 100 & 0 & $29 \pm 0$ & 一 \\
\hline 'rhodochrous' R90 & I I $\pm \mathbf{I}$ & 13 & - & 9 & 0 & $3 I \pm 3$ & 14 & 100 & 一 \\
\hline
\end{tabular}

For definition of $\Delta T_{m(e)}$, and specific activities of DNA from the reference strains, see Table 2. 


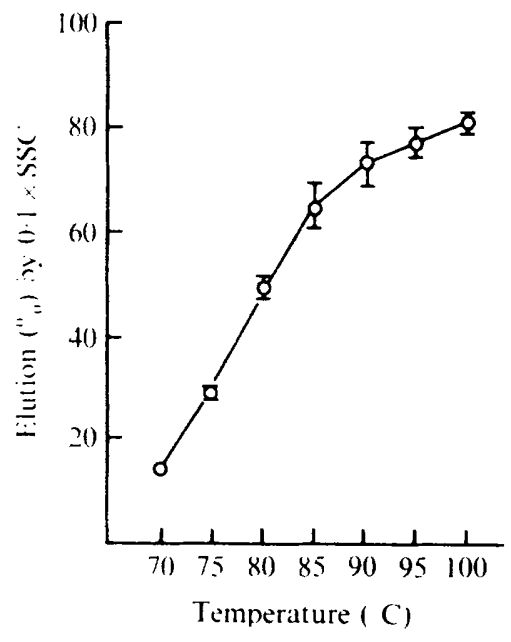

Fig. 1

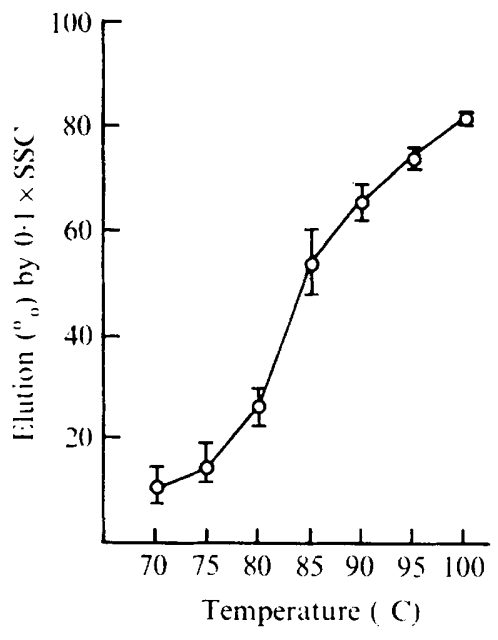

Fig. 2

Fig. I. Thermal elution profile of DNA : DNA duplexes of $N$. pellegrino PI I and $N$. pellegrino PIO. See Methods for details.

Fig. 2. Thermal elution profile of homologous DNA: DNA duplexes of Gordona terrae T5. See Methods for details.

rhodochrous strain R5. Five of the rhodochrous strains bound between 22 and $31 \%$ of reference $N$. pellegrino DNA and an equivalent affinity was found between some of these strains and the $G$. bronchialis and $G$. terrae reference systems (Table 3).

A low degree of homology was exhibited between DNA preparations from the Gordona strains and DNA from $N$. asteroides $\mathrm{NK2O}, N$. pellegrino PI I and the rhodochrous strain R9O (Table 4 ). The highest affinity was the $28 \%$ nucleotide sequence homology found between $G$. terrae $\mathrm{T} 5$ and the rhodochrous reference system. Similarly comparatively little affinity was exhibited between the DNA from $G$. rubra and $G$. terrae and that from the G. bronchialis reference system. The two $G$. bronchialis strains, however, shared a similarity of $100 \%$. In contrast, $G$. terrae T6 only bound $44 \%$ of the DNA from the $G$. terrae reference system. The thermal elution profile of the homologous DNA:DNA duplex of G. terrae $\mathrm{T}_{5}$ is shown in Fig. 2.

In most of the reassociation experiments the thermal stability of the molecular hybrids was similar to those formed in the homologous systems, although lower thermal stabilities of heterologous DNA duplexes were often noted.

\section{DISCUSSION}

Good congruence has been observed between nucleotide sequence homology and numerical phenetic data in a number of genera (Sneath, 1972; Kersters et al., 1973; Colwell et al., 1974; Staley \& Colwell, 1973) and in some actinomycete taxa (Gross \& Wayne, 1970; Farina \& Bradley, 1970; Okanishi \& Gregory, 1970; Bradley, 1972). In most cases, strains classified in a homogeneous species share at least $70 \% \mathrm{DNA}$, and lower binding values are considered to reflect significant genetic divergence (Brenner, 1973). However, it is still difficult to equate homology and similarity values, or to formally relate either of them to levels in the taxonomic hierarchy. Similarly coefficients can be severely distorted by factors 
such as sampling error, poor test reproducibility and failure to account for differences in growth rate and metabolic activity. On the other hand, the techniques used to determine DNA homology are complex and may not be free from significant experimental errors. Our estimates of genetic resemblance should not, therefore, be regarded as absolute values.

In some of the experiments described, large amounts of labelled DNA were needed, for instance, with the rhodochrous strain R9o the speciflc activity of the reference DNA was 2764 c.p.m. $/ \mu$ g. However, using $25 \mathrm{~mm}$ discs, sufficient labelled DNA was bound for reproducibility despite the low specific activity. In the homologous systems 20 to $30 \%$ pairing (3500 to 18000 c.p.m./sample) was found and taken as $100 \%$.

Only a small degree of genetic relatedness existed between the Nocardia asteroides reference system and the rest of the taxa studied. Although only one Nocardia strain was examined the results support numerical, chemical and serological studies (Ridell, 1974; Goodfellow et al., 1974; Alshamaony et al., 1976a) which suggest that the 'rhodochrous' complex should not be classified in the genus Nocardia sensu stricto (Cross \& Goodfellow, 1973). They also support the view (Tsukamura, 197I) that the genera Gordona and Nocardia are related but distinct.

The internal structure of the 'rhodochrous' complex is gradually being revealed but it is still difficult to draw boundaries between the various clusters recovered (Goodfellow, I97 I ; Goodfellow et al., 1974). It was, therefore, encouraging that nearly all of the representatives of phenon I $a$ (Goodfellow et al., I974), the $N$. rubra taxon (Bradley, I97I), formed a tightly knit group in which the strains shared $80 \%$ or more DNA with the rhodochrous reference system. However, the DNA base composition range of the constituent strains, 63 to $69 \%$ GC, was wider than that reported for $N$. rubra (Bradley, 197I). Nevertheless, I $a$ forms a good cluster on the basis of numerical phenetic, chemical, serological (Goodfellow et al., 1974; Alshamaony et al., 1976a) and genetic data. The only representative of the rhodochrous phenon $\mathrm{I} b$ (Goodfellow et al., I974), rhodochrous strain R35, shared little genetic affinity with any of the reference strains studied. Additional representatives of phenon $\mathrm{I} b$ need to be examined to see whether they share a high DNA homology with reference DNA from strain $\mathbf{R} 35$.

The strains labelled $N$. pellegrino form a homogeneous taxon on the basis of chemical and fermentation studies (Mordarska, Mordarski \& Pietkiewicz, 1973), and there is strong evidence that they also comprise a good cluster in the 'rhodochrous' complex (M. Goodfellow, unpublished data). This $N$. pellegrino taxon forms a genetically homogeneous group with all but one of the strains showing $82 \%$ or more binding with DNA from the reference pellegrino strains. Values of DNA relatedness ranging from 20 to $30 \%$ were obtained between the rhodochrous reference strains and the pellegrino strains. The pellegrino strains exhibited a DNA base composition range of 66 to $69 \%$ GC so they cannot be differentiated from the other rhodochrous strains on this basis.

The nucleotide sequence homology data suggested that G. bronchialis, G. rubra, and more equivocally $G$. terrae, formed good species. However, the values for DNA relatedness between these three taxa, and between them and the rhodochrous homology groups, were comparatively low. Gordonae have also been distinguished from rhodochrous strains in antibiotic sensitivity studies (Goodfellow \& Orchard, 1974) and in lipid analyses (Alshamaony et al., 1976 b). On the basis of numerical phenetic data, Tsukamura (1973, 1974) has classified a number of rhodochrous strains in new species within the genus Gordona. The DNA base composition range of the gordonae is similar to that shown by nocardiae, mycobacteria and rhodochrous strains. 
Clearly more extensive numerical and nucleotide sequence homology analyses are required to unravel the complicated taxonomic relationships between Gordona and rhodochrous clusters, and our studies are being continued.

\section{REFERENCES}

Adams, M. M., Adams, J. N. \& Brownell, G. H. (1970). The identification of Jensenia canicruria Bisset and Moore as a mating type of Nocardia erythropolis (Gray and Thornton) Waksman and Henrici. International Journal of Systematic Bacteriology 20, 133-148.

Alshamaony, L., Goodfellow, M. \& Minnikin, D. E. (1976a). Free mycolic acids as criteria in the classification of Nocardia and the 'rhodochrous' complex. Journal of General Microbiology 92, 188-199.

Alshamaony, L., Goodfellow, M., Minnikin, D. E. \& Mordarska, H. (1976b). Free mycolic acids as criteria in the classification of Gordona and the 'rhodochrous' complex. Journal of General Microbiology 92, I $83-187$.

Bradley, S. G. (197I). Criteria for definition of Mycobacterium, Nocardia and the rhodochrous complex. Advancing Frontiers of Plant Sciences 28, 349-362.

BRADLEY, S. G. (1972). Reassociation of deoxyribonucleic acid from selected mycobacteria with that from Mycobacterium bovis and Mycobacterium farcinica. American Review of Respiratory Diseases 106, I22124.

BRADLEY, S. G. (1973). Relationships among mycobacteria and nocardiae based upon deoxyribonucleic acid reassociation. Journal of Bacteriology 113, 645-651.

Bradley, S. G. \& Huitron, M. E. (1973). Genetic homologies among nocardiae. Developments in Industrial Microbiology 14, 189-199.

Bradley, S. G., Brownell, G. H. \& Clark, J. (1973). Genetic homologies among nocardiae and other actinomycetes. Canadian Journal of Microbiology 19, 1007-1014.

BrAY, G. A. (1960). A simple efficient liquid scintillator for counting aqueous solutions in a liquid scintillation counter. Analytical Biochemistry r, 279-285.

BRenNeR, D. J. (1973). Deoxyribonucleic acid reassociation in the taxonomy of enteric bacteria. International Journal of Systematic Bacteriology 23, 298-307.

Colwell, R. R., Johnson, R., Wan, L., Lovelace, T. E. \& Brenner, D. J. (1974). Numerical taxonomy and deoxyribonucleic acid reassociation in the taxonomy of some Gram-negative fermentative bacteria. International Journal of Systematic Bacteriology 24, 422-433.

Cross, T. \& Goodfellow, M. (1973). Taxonomy and classification of the actinomycetes. In Actinomycetes: Characteristics and Practical Importance, pp. I I-1 2 I. Edited by F. A. Skinner and G. Sykes. London: Academic.

DE LeY, J. \& Tistgat, R. (1970). Evaluation of membrane filter methods for DNA : DNA hybridization. Antonie van Leeuwenhoek 36, 46I-474.

Farina, G. \& Bradley, S. G. (1970). Reassociation of deoxyribonucleic acids from Actinoplanes and other actinomycetes. Journal of Bacteriology 102, 30-35.

GOodfellow, M. (197I). Numerical taxonomy of some nocardioform bacteria. Journal of General Microbiology 69, 33-80.

Goodfellow, M., Fleming, A. \& SACKIN, M. J. (1972). Numerical classification of 'Mycobacterium' rhodochrous and Runyon's group IV mycobacteria. International Journal of Systematic Bacteriology 22, $8 \mathrm{i}-98$.

Goodfellow, M., Lind, A., Mordarska, H., Pattyn, S. \& Tsukamura, M. (1974). A co-operative numerical analysis of cultures considered to belong to the 'rhodochrous' complex. Journal of General Microbiology $85,291-302$.

Goodfellow, M. \& ORCHARD, V. A. (1974). Antibiotic sensitivity of some nocardioform bacteria and its value as a criterion for taxonomy. Journal of General Microbiology 83, 375-387.

Gross, N. M. \& WAYNE, L. G. (1970). Nucleic acid homology in the genus Mycobacterium. Journal of Bacteriology 104, 630-634.

HuANG, P. C. \& RosenBerg, E. (1966). Determination of DNA base composition via depurination. Analytical Biochemistry 16, 107-113.

JONES, D. (1975). A numerical taxonomic study of coryneform and related bacteria. Journal of General Microbiology 87, 52-96.

Kersters, K., De Ley, J., Sneath, P. H. A. \& Sackin, M. (1973). Numerical taxonomic analysis of Agrobacterium. Journal of General Microbiology 78, 227-239.

Legault-Demare, J., Desseaux, N., Heyman, T., Seror, S. \& Ress, G. F. (1967). Studies on hybrid molecules of nucleic acids. I. DNA : DNA hybrids on nitrocellulose filters. Biochemical and Biophysical Research Communications 28, 550-557.

MordarsKa, H., Mordarski, M. \& Goodfellow, M. (1972). Chemotaxonomic characters and classification of some nocardioform bacteria. Journal of General Microbiology 7r, 77-86. 
Mordarska, H., Mordarski, M. \& Pietkiewicz, D. (I973). Chemical analysis of hydrolysates and cell extracts of Nocardia pellegrino. International Journal of Systematic Bacteriology 23, 274-277.

OKANISHI, M. \& GREGORY, K. F. (I970). Methods for the determination of deoxyribonucleic acid homologies in Streptomyces. Journal of Bacteriology 104, 1086-1094.

RIDELL, M. (1974). Serological study of nocardiae and mycobacteria by using 'Mycobacterium' pellegrino and Nocardia corallina precipitation reference systems. International Journal of Systematic Bacteriology 24, 64-72.

RIDELI, M. \& NorLIN, M. (1973). Serological study of Nocardia by using mycobacterial precipitation reference systems. Journal of Bacteriology $11_{3}, \mathrm{I}-7$.

Saito, H. \& MiURA, K. I. (1963). Preparation of transforming deoxyribonucleic acid by phenol treatment. Biochemica et biophysica acta 72, 619-629.

SNeAth, P. H. A. (1972). Computer taxonomy. In Methods in Microbiology, vol. 7A, pp. 29-98. Edited by J, R. Norris and R. W. Ribbons. London: Academic.

Staley, T. E. \& Colwell, R. R. (1973). Deoxyribonucleic acid reassociation among members of the genus Vibrio. International Journal of Systematic Bacteriology 23, 316-332.

Tacquet, A., Plancot, M. T., Debruyne, J., Devulder, B., Joseph, M. \& Losfeld, J. (1971). Etudes preliminaires sur la classification numérique des mycobacteries et des nocardias. r. Relations taxonomiques entre Mycobacterium rhodochrous, Mycobacterium pellegrino et les genres Mycobacterium et Nocardia. Annales de l'Institut Pasteur de Lille 22, $121-135$.

Tsukamura, M. (1971). Proposal of a new genus, Gordona, for slightly acid-fast organisms occurring in sputa of patients with pulmonary disease and in soil. Journal of General Microbiology 66, 15-26.

Tsukamura, M. (1973). A taxonomic study of strains received as 'Mycobacterium' rhodochrous. Description of Gordona rhodochroa (Zopf; Overbeck; Gordon et Mihm) Tsukamura comb. nov. Japanese Journal of Microbiology 17, I89-197.

TsukamuRA, M. (1974). A further numerical taxonomic study of the rhodochrous group. Japanese Journal of Microbiology 18, 37-44.

Yamada, K. \& KomaGata, K. (1970). Taxonomic studies on coryneform bacteria. 3. DNA base composition of coryneform bacteria. Journal of General and Applied Microbiology 16, 21 5-224. 